Article

\title{
Genetic Damage in Workers from the Rare Metal Ore Production Region
}

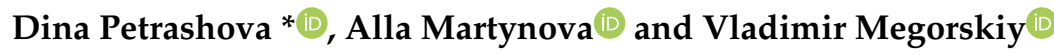 \\ Research Centre for Human Adaptation in the Arctic, Kola Science Centre, Russian Academy of Sciences, \\ Apatity 184209, Russia; martynovaalla@ya.ru (A.M.); megorsky@ya.ru (V.M.) \\ * Correspondence: dinapetrashova@mail.ru; Tel.: +7-9113221229
}

Received: 31 December 2018; Accepted: 22 February 2019; Published: 25 February 2019

\begin{abstract}
The aim of this study was to assess the genotoxic and cytotoxic effects that occur in miners working underground in rare metal ore mines at ionizing radiation levels within the maximum permissible concentration (MPC) standards using the buccal micronucleus cytome (BMCyt) assay. At the same time, we attempted to identify possible relationships between cytogenetic abnormalities in the buccal epithelium and such physiological indicators as cardiodynamics and the body mass index. The study involved a total of 269 individuals, 236 miners working underground in production related to the mining and enrichment of loparite ores and 33 non-exposed individuals (Russia, Murmansk region). Buccal micronucleus cytome assay and heart rate variability parameters were used. Micronucleus frequency was revealed to be a higher in the exposed group $(8.3 \pm 1.08 \%)$ than in the non-exposed group $(3.3 \pm 0.49 \%)$. The repair index showed a statistically significant increase in the non-exposed group $(14.9 \pm 2.90)$ compared with the exposed group $(6.1 \pm 0.74)$. The frequency of nuclear protrusions correlates significantly with the body mass index in the young miners ( $\leq 30$ years $(r=0.45))$. There is a negative relationship between the micronucleus frequency and the level of organism adaptation $(r=-0.24)$, the vegetative regulation rate $(r=-0.20)$ and the psycho-emotional state $(r=-0.30)$ for miners older than 30 years. The results testify to the possible induction of clastogenic effects and a decrease in the level of reparation in the buccal epithelium cells due to the exposure of a various of production factors in the extraction of loparite ore.
\end{abstract}

Keywords: micronucleus; buccal cell; repair index; heart rate variability; body mass index; miner; ionizing radiation; radon

\section{Introduction}

Underground miners are exposed to harmful factors such as dust, the underground environment, industrial noise, light environment, vibration, low temperature, physical overload. The health of miners is especially endangered when the underground mining of ore contains such natural radionuclides as uranium, thorium, and radium. This is due to inhalation and ingestion of dust particles containing radium, the inhalation of radon and its decay products and the external irradiation of the body and inhalation of dust of mixed particles of radioisotopes [1,2].

The pathophysiological effect of radiation loads exceeding the maximum permissible concentration (MPC) has been well studied and described both theoretically and clinically in many works [3-7]. Of particular interest is the response of the human body to the loads generated by radiation much higher than the average background values exceeding them by $3-4$ times, but within the MPC standards. These values are comparable to the loads of pilots, flight attendants, cosmonauts and the workers of some enterprises and mines [8-16]. The study of data "Effects-Response" will allow us to consider questions related to revisions and clarifications of the norms of the MPC. These questions 
include changes in working conditions, evaluation of the effects associated with the accumulation of these changes over a long period of time and the modelling of the resulting effects.

The homeostasis of the body may be maintained depending on the balance between DNA damage and the repair response. Violation of this balance can cause a wide range of human pathologies. Genetic instability and oxidative stress are risk factors for cancer and cardiovascular diseases (CVD) $[17,18]$. Oxidative stress causes DNA damages, apoptosis and inflammation. Therefore, it can lead to the emergence of heart fibrosis and plays an important role in the occurrence of heart failure and left ventricular remodeling in diabetic cardiomyopathy $[19,20]$.

To identify the genotoxic effects of radiation exposure, the micronucleus test is most widely used whenever cultured cells of peripheral blood lymphocytes are under cytokinetic block conditions. It allows the analysis of the entire spectrum of changes characterizing genome instability $[5,21,22]$. However, in certain cases, it is preferable to study genotoxic effects on the buccal epithelium, since it is the first barrier [23], that occurs on the path of carcinogens during breathing, drinking and eating food. The buccal micronucleus cytome assay (BMCyt assay) is characterized by minimal invasive intervention and provides information on genotoxic loads during three weeks of exposure [23]. This method is fast and simple for biomonitoring human population exposed to environmental genotoxic agents [24,25].

The main purpose of this study was to assess the genotoxic and cytotoxic effects that occur in miners working underground in rare metal ore mines at ionizing radiation levels within the MPC standards using the BMCyt assay. At the same time, we attempted to identify possible relationships between cytogenetic abnormalities in the buccal epithelium and such physiological indicators as cardiodynamics and the body mass index.

\section{Materials and Methods}

\subsection{Study Area}

The participants in this study were miners working underground in production related to the mining and enrichment of loparite ores (Lovozero district, Murmansk region, Russia, $67.9372^{\circ} \mathrm{N}$ $34.5594^{\circ} \mathrm{E}$ ) and the control group of healthy subjects living in the city of Apatity (Murmansk region, Russia, $\left.67^{\circ} 34^{\prime} \mathrm{N} 33^{\circ} 24^{\prime} \mathrm{E}\right)$. The study was conducted during December 2013 to eliminate the effects of air pollution characteristic of the summer months.

Lovozero district. The main sources of pollution are: (a) An enterprise for the extraction and processing of rare-earth ores; (b) Thermal power plants; (c) Motor vehicles. Radio-ecological researches in this region of rare metal ore production with high content of natural radionuclides showed that the gamma-phone recordings for this mine are at a level $0.1-1.5 \mu \mathrm{Sv} / \mathrm{h}$ and do not exceed normative value in these conditions of underground mining. The radon concentration in the underground waters near the settlement exceeded intervention level around 1.3 times [26].

Apatity. The main sources of pollution: (a) Enterprises for the extraction and processing of apatite-nepheline ores; (b) Thermal power plants; (c) Vehicles; (d) Railway transportation. During the summer months the atmosphere of Apatity displayed increased concentrations of suspended substances. Moreover, when summer north-westerly winds were observed, one-time concentrations of suspended solids and small suspended particles of PM10 were up to 2 MAC. However, the average summer monthly concentrations of suspended substances only reached up to 1.0 MAC [27].

According to the 2013 data, both towns were characterized as settlements with a low level of atmospheric pollution [27].

\subsection{Ethical Consideration}

This study was approved by the Committee on Ethics at Hospital KSC RAS (163/2013) and informed consent was obtained from each participant. 


\subsection{Participants}

The study involved a total of 269 individuals, 236 miners and 33 non-exposed individuals.

The inspection of miners who gave consent was conducted at the medical assistant's station before the start of the morning shift. The control group was formed from volunteers who responded to an advertisement in the local newspaper. We had to establish very tight deadlines for the work since the study took place during the polar night in the Murmansk region. Because of this time limit, we were forced to limit ourselves to a small sample of the non-exposed group.

All individuals were adult male because there are effects of sex due to biological differences that include a sex-related aneuploidy phenomenon and the implication of sexual hormones [28].

A questionnaire was applied by researchers to collect information, including determination of standard demographic data and questions concerning personal data, medical issues, weight and height, vaccination, vitamin, medication, exposure to $X$-rays, family history of cancer and brief medical information regarding about chronic chronicle diseases, life style (smoking, alcohol consumption, etc.), length of service (only for exposed groups), diet, and other socioeconomic factors (Russian validated version of the Medical Outcomes Study Short Form-36 [29], SAN Tests [30], personal anxiety-Spielberg questionnaire [31]. Current smokers were defined as those who had been smoking at last six months before buccal sample collections. All of the participants had a mixed diet.

Exclusion criteria for both groups: a history of a participant's cancer and his parents, chronic lung disease, diabetes. Exclusion criteria for the non-exposed group: Consumption of vitamins in the last month, exposure to medical radiation in the last six months, occupational exposure, age over 30 years.

The selection of a group up to 30 years is determined by the following reasons. Firstly, in this age group, functional changes in the cardiovascular system have not yet begun. Secondly, in people under the age of 30, moderate chronic pathology is assumed [32]. Thirdly, the greater consistency of the workplace and place of residence. In the older group it is more difficult to take into account the facts of changing the place of work and place of residence.

Buccal cells were obtained from all individual that met the specified criteria. Heart rate variability (HRV) data received for 130 individuals from the exposed group because some of the subjects refused to complete this part of the study.

\subsection{Buccal Micronucleus Cytome Assay}

Buccal cells were collected from each individual using sterile wooden spatulas. The individuals were asked to rinse their mouths with water before sampling. The biological samples were stored in tubes containing $10 \mathrm{~mL}$ of saline solution. Then the samples were washed, fixed on slides and stained with acetoorseine. A total of 2000 cells per sample were analyzed under $1000 \times$ magnification an oil immersion using with a light microscope (AXIOSTAR PLUS, Karl Zeiss, Oberkochen, Germany) to estimate micronuclei $(\mathrm{MN})$ and nuclear abnormalities frequencies following the protocol described by Thomas et al. [33]. The following was considered: (a) Cells with DNA damages (micronuclei (MN), nuclear bud, broken egg); (b) Cells with cytokinetic failure (binucliated cells, doublenucliated cells); (c) Cell death features (condensed chromatin, karyorhexis, picnosis, karyolisis and cells with apoptotic bodies).

\subsection{Physiological Indicators}

Physiological indicators were evaluated by the parameters of cardiohemodynamics: heart rate variability (HRV) and blood pressure, in accordance with the standards adopted by the European Society of Cardiology and the North American Society of Electrostimulation and Electrophysiology in 1996 [34]. Systolic (ADS) and diastolic (ADD) blood pressure, heart rate (HR) and heart rate variability (HRV) were measured in the supine position for $5 \mathrm{~min}$, after $3 \mathrm{~min}$ of pre-adaptation at rest. The registration of HRV (sampling rate of $1000 \mathrm{~Hz}$ ) and the analysis of HRV were performed using an Omega-M instrument (NPF Dynamika, St. Petersburg, Russia). The analysis of the integral indicators 
of HRV was carried out according to the results of the frequency and time analysis of HRV. From these recordings they calculated: the level of adaptation of the cardiovascular system, the indicator of vegetative regulation, the psycho-emotional state, and the stress index of regulatory mechanisms [35].

A limitation of this study: (a) The sample size of the non-exposed control group; (b) The use of only non-invasive methods was a prerequisite for this study. Therefore, we could not obtain additional biological samples and were limited to using only the BMCyt assay; (c) HRV data received only for 130 individuals from the exposed group, no date for non-exposed group.

\subsection{Statistical Analysis}

All the resulting data was recorded in the spatial database [36]. The number of micronuclei and other nuclear anomalies per 1000 buccal cells were expressed as means + mean-square error. The repair index was calculated as $\mathrm{RI}=(\mathrm{KL}+\mathrm{KR}) /(\mathrm{MN}+\mathrm{BE})$, where $\mathrm{KL}-$ Kariolisis, $\mathrm{KR}-\mathrm{K}$ aryorhexis, $\mathrm{MN}-$ Micronucleus, BE-Broken eggs [37]. The differences in the composition of groups were assessed by a two-sided criterion of the $\chi^{2}$ correspondence statistical analysis, the differences in the results of the BMCyt assay were assessed according to the U-criterion of Mann-Whitney Test. Correlation analysis was carried out using the Spearman rank test. The critical level for rejection of the null hypothesis was considered to be $5 \%(p<0.05)$. The statistical analysis was performed with the Statistica 10.0 statistical software package.

\section{Results}

The characteristics of the study population including lifestyle, individual health problems and sociodemographic indicators are presented in Table 1. As can be seen, the miners and non-exposed groups differed in age. Therefore, the young miners group ( $\leq 30$ years) was selected from all miners group and shown separately.

Table 1. Prevalence of sociodemographic characteristics of the exposed and non-exposed groups.

\begin{tabular}{cccc}
\hline Parameters & All Miners & Young Miners & Non-Exposed Group \\
\hline $\mathrm{n}$ & 236 & 48 & 33 \\
age & $43.7 \pm 0.81$ & $26.3 \pm 0.35$ & $25.9 \pm 0.27$ \\
Time of mining service, ages & $15.7 \pm 0.82$ & $4.0 \pm 0.34$ & - \\
Consumption of cigarettes & & & \\
yes & $67.4 \%(159)$ & $79.2 \%(38)$ & $78.8 \%(26)$ \\
not anymore & $6.4 \%(15)$ & $4.2 \%(2)$ & 0 \\
no & $26.3 \%(62)$ & $16.7 \%(8)$ & $21.2 \%(7)$ \\
\hline Consumption of alcoholic beverage & & & 0 \\
every day & $0.4 \%(1)$ & $2.1 \%(1)$ & $12.1 \%(4)$ \\
weekly & $21.6 \%(51)$ & $22.9 \%(11)$ & $81.8 \%(27)$ \\
seldom & $73.3 \%(173)$ & $72.9 \%(35)$ & $6.1 \%(2)$ \\
no & $4.7 \%(11)$ & $2.1 \%(1)$ & $39.4 \%(13)$ \\
yes & & & $60.6 \%(20)$ \\
no & $25 \%(59)$ & $47.9 \%(23)$ & $3.0 \%(1)$ \\
Catch cold in the last month & $75 \%(177)$ & $52.1 \%(25)$ & $97 \%(32)$ \\
yes & & & 0 \\
no & $7.6 \%(18)$ & $16.7 \%(8)$ & $100 \%(33)$ \\
\hline Consumption of antibiotic in the last month & $92.4 \%(218)$ & $83.3 \%(40)$ & 0 \\
nes & & & $100 \%(33)$ \\
\hline Consumption of vitamins in the last month & $32.6 \%(77)$ & $29.2 \%(14)$ & \\
\hline no & $67.4 \%(159)$ & $70.8 \%(34)$ & \\
\hline & $7.2 \%(17)$ & $2.1 \%(1)$ & $97.9 \%(47)$ \\
\hline
\end{tabular}


Comparisons of the sociodemographic characteristics between the groups show significant differences between all miners and young miners groups for catching cold $\left(\chi^{2}=10.2, p<0.05\right)$ and consumption of antibiotic in the last month $\left(\chi^{2}=3.9, p<0.05\right)$. The non-exposed group demonstrates significant differences from all the miners and young miners groups for the consumption of vitamins during the last month $\left(\chi^{2}=11.6\right.$ and $\left.\chi^{2}=15.1, p<0.05\right)$.

The analysis of the psychophysiological states from the SAN tests (well-being, activity and mood), Spielberger-Khanin (situational and personal anxiety) and SF-36 did not show significant differences between the groups.

The results of the BMCyt assay are presented in Table 2. The comparison of sociodemographic characteristics within the exposed group showed only a significant difference for the consumption of vitamins and exposure to medical radiation in the last six months $(p<0.05$, Mann-Whitney test).

Table 2. Frequencies of micronucleus and other nuclear anomalies in exfoliated buccal epithelial cells.

\begin{tabular}{|c|c|c|c|}
\hline Parameters & All Miners & Young Miners & Non-Exposed Group \\
\hline $\mathrm{n}$, all & 236 & 48 & 33 \\
\hline $\mathrm{n}$, no vitamins and medical X-ray & 147 & 33 & \\
\hline Micronuclei, \%o & $\begin{array}{l}7.9 \pm 0.54^{* *} \\
8.1 \pm 0.66^{* * *}\end{array}$ & $\begin{array}{l}8.3 \pm 1.08^{* *} \\
9.3 \pm 1.28^{* * *}\end{array}$ & $3.3 \pm 0.49$ \\
\hline Nuclear bud, $\%$ & $\begin{array}{l}0.9 \pm 0.26^{* * *} \\
1.0 \pm 0.38^{* *}\end{array}$ & $\begin{array}{l}0.8 \pm 0.30 * \\
0.6 \pm 0.26^{*}\end{array}$ & $4.0 \pm 1.15$ \\
\hline Broken egg, $\%$ & $\begin{array}{c}0.1 \pm 0.05 \\
0\end{array}$ & $\begin{array}{l}0.2 \pm 0.14 \\
0.2 \pm 0.06\end{array}$ & $0.4 \pm 0.16$ \\
\hline Two nuclei, $\%$ & $\begin{array}{l}4.9 \pm 0.49 \\
2.3 \pm 0.58\end{array}$ & $\begin{array}{l}3.4 \pm 0.67 \\
3.8 \pm 0.87\end{array}$ & $3.5 \pm 0.57$ \\
\hline Double nuclei, \%o & $\begin{array}{l}1.2 \pm 0.22 \\
1.2 \pm 0.30\end{array}$ & $\begin{array}{l}1.2 \pm 0.60 \\
0.8 \pm 0.71\end{array}$ & $0.7 \pm 0.19$ \\
\hline Condensed chromatin, $\%$ & $\begin{array}{l}11.8 \pm 0.54^{* * *} \\
12.2 \pm 0.67^{* * *}\end{array}$ & $\begin{array}{l}12.0 \pm 1.11^{* * *} \\
12.5 \pm 1.31^{* * *}\end{array}$ & $3.9 \pm 0.64$ \\
\hline Karyorrhexis, \% & $\begin{array}{l}0.8 \pm 0.07^{* * * *} \\
0.7 \pm 0.09^{* * *}\end{array}$ & $\begin{array}{l}0.7 \pm 0.10^{* * *} \\
0.7 \pm 0.12^{\text {*** }}\end{array}$ & $0.2 \pm 0.05$ \\
\hline Piknosis, \% & $\begin{array}{l}1.5 \pm 0.06^{* * *} \\
1.4 \pm 0.08^{* * *}\end{array}$ & $\begin{array}{l}1.6 \pm 0.13^{* * *} \\
1.6 \pm 0.20^{\text {*** }}\end{array}$ & $0.5 \pm 0.10$ \\
\hline Kariolisis, \% & $\begin{array}{l}52.1 \pm 1.16^{* * *} \\
51.7 \pm 1.49^{* * *}\end{array}$ & $\begin{array}{l}49.5 \pm 2.59^{* * *} \\
50.3 \pm 3.02^{* * *}\end{array}$ & $76.1 \pm 3.21$ \\
\hline Apoptotic bodies, $\%$ & $\begin{array}{l}5.1 \pm 0.59^{* *} \\
5.1 \pm 0.64^{* *}\end{array}$ & $\begin{array}{c}6.7 \pm 2.03^{* *} \\
4.4 \pm 0.97^{*}\end{array}$ & $2.3 \pm 0.59$ \\
\hline Repair index, RI & $\begin{array}{l}6.2 \pm 0.36^{* *} \\
6.4 \pm 0.44^{* *}\end{array}$ & $\begin{array}{l}6.1 \pm 0.74 \text { ** } \\
5.8 \pm 0.81^{* *}\end{array}$ & $14.9 \pm 2.90$ \\
\hline
\end{tabular}

${ }^{*} p<0.05 ;{ }^{* *} p<0.01 ;{ }^{* * *} p<0.001$ compared with non-exposed group (the Mann-Whitney test).

The average frequencies of cells with micronuclei $(\mathrm{MN})$ in the non-exposed group do not exceed the baseline frequencies for micronucleated cells- 2-5\% [28]. The evaluation of buccal cells revealed a higher frequency of cells with $\mathrm{MN}$ in exposed groups than in the non-exposed group $(p<0.01$, Mann-Whitney test). However, the exposed groups had a significantly lower frequency of cells with a nuclear bud than the non-exposed group ( $p<0.05$, Mann-Whitney test).

The exposed groups presented significantly higher frequency of cells with condensed chromatin, karyorrhexis, piknosis $(p<0.001$, Mann-Whitney test) and apoptotic bodies $(p<0.01$, Mann-Whitney test). The exposed groups had a significantly lower frequency of cells with karyolisis $(p<0.001$, Mann-Whitney test). The repair index showed a statistically significant increase in buccal cells of the non-exposed group compared with the exposed group ( $p<0.01$, Mann-Whitney test). Analysis of the parameters of cardiohemodynamics showed that, on average, the blood pressure (arterial pressure) and heart rate (heart rate, beat/min) parameters are within the age group (Table 3). Only in a group over 30 years old is systolic blood pressure (systolic blood pressure, SYS) slightly higher than normal. 
Table 3. Physiological state of the miners.

\begin{tabular}{ccc}
\hline Parameters & $\begin{array}{c}\text { Miners } \\
>\mathbf{3 0 ~} \mathbf{~ r r}\end{array}$ & $\begin{array}{c}\text { Miners } \\
<\mathbf{3 0 ~} \mathbf{~ r ~}\end{array}$ \\
\hline $\mathrm{n}$ & 98 & 32 \\
Age, yr & $47.8 \pm 0.99^{* * *}$ & $26.5 \pm 0.41$ \\
Heart rate, beat/min & $80.3 \pm 1.27$ & $82.9 \pm 2.35$ \\
Systolic blood pressure & $126.3 \pm 1.04^{* * *}$ & $118.4 \pm 1.09$ \\
Diastolic blood pressure & $85.2 \pm 0.79^{* * *}$ & $78.0 \pm 1.18$ \\
Growth, cm & $176.2 \pm 0.7$ & $178.8 \pm 1.17$ \\
Weight, $\mathrm{kg}$ & $82.5 \pm 1.36$ & $77.4 \pm 2.30$ \\
Body mass index, kg/m ${ }^{2}$ & $26.6 \pm 0.38^{* * *}$ & $155.9 \pm 0.64$ \\
Stress index, c.u. & $257.8 \pm 22.28^{* * *}$ & $54.1 \pm 4.56$ \\
Level of Body Adaptation & $32.9 \pm 2.34^{* * *}$ & $59.2 \pm 5.25$ \\
Vegetative regulation index & $41.7 \pm 2.70^{* *}$ & $53.5 \pm 4.08$ \\
Central Regulation Indicator & $38.7 \pm 2.23^{* *}$ & $57.1 \pm 3.44$ \\
Psycho-emotional state & $40.1 \pm 2.15^{* *}$ &
\end{tabular}

$$
{ }^{*} p<0.05 ;{ }^{* *} p<0.01 ;{ }^{* * *} p<0.001 \text { - the Mann-Whitney test. }
$$

With age, there is a marked increase in the voltage index of regulatory mechanisms (stress index SI), a decrease in the level of adaptation of the cardiovascular system, vegetative regulation and psycho-emotional state. The assessment of vegetative tonus based on heart rate variability analysis showed that in the group of up to 30 years the normotonic $46.8 \%$ and vagotonic $43.7 \%$ dominate the type of vegetative regulation, sympathotonic type is observed only in $9.5 \%$. In the group older than 30 , the influence of the sympathetic nervous system increases: normotonics $-50.0 \%$, vagotonics $-22.5 \%$, sympathotonics-26.5\%.

Analysis of the body mass index (body mass index, $\mathrm{kg} / \mathrm{m}^{2}$ ) showed that in the group of up to 30 years old, $62.5 \%$ had normal body weight, $7 \%$ were overweight, $6.3 \%$ had obesity grade I, and $9.3 \%$ were underweight. In the group older than 30 years, the percentage of people with normal weight decreased to $46.9 \%$, the number of overweight people increased to 29.6 , obesity grade I $-19.4 \%$ and obesity grade II- $4.1 \%$.

A correlation analysis was performed regarding the dependence of the frequency of nuclear anomalies upon the physiological state of the organism in miners under the age of 30 years $(n=32)$ and over 30 years $(n=98)$. It was shown that in miners under the age of 30 years, the frequency of nuclear protrusions correlates significantly with the body mass index $(r=0.45, p \leq 0.05)$ (Figure 1).

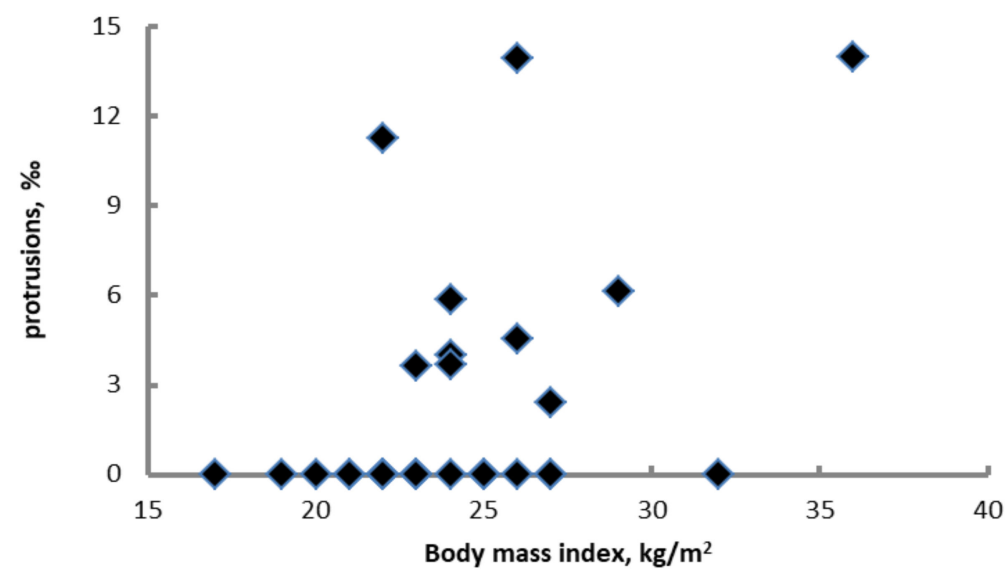

Figure 1. Positive association between the frequency of nuclear protrusions (\%) and the body mass index in miners under the age of 30 years $\left(\mathrm{kg} / \mathrm{m}^{2}\right)$. 
For miners older than 30 years, there is a negative relationship between the frequency of cells with $\mathrm{MN}$ and the level of body adaptation $(r=-0.24, p \leq 0.05)$, the rate of vegetative regulation $(r=-0.20$, $p \leq 0.05)$ and the psycho-emotional state $(r=-0.30, p \leq 0.05)$. The frequency of cells with $\mathrm{MN}$ is reliably associated with the stress index $(r=0.21, p \leq 0.05)$ (Figure 2).

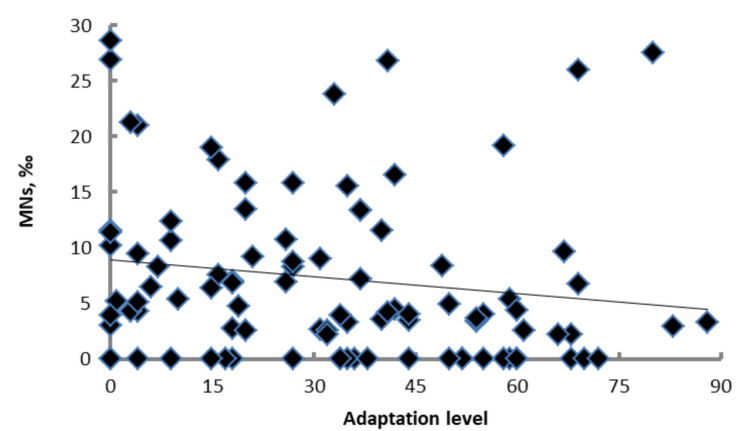

a)

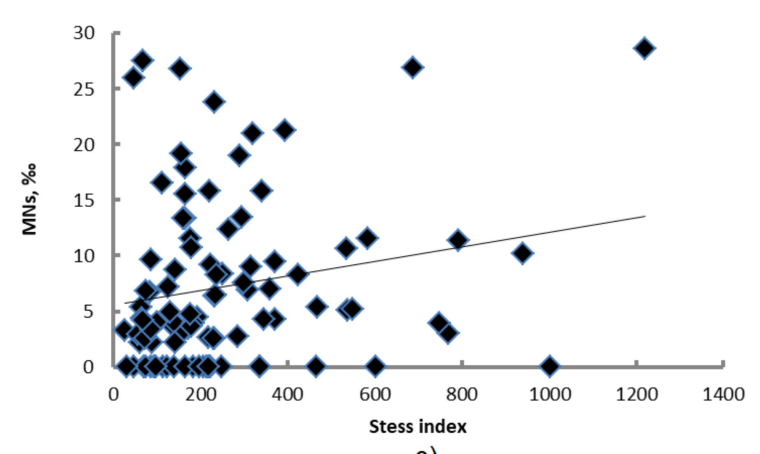

c)

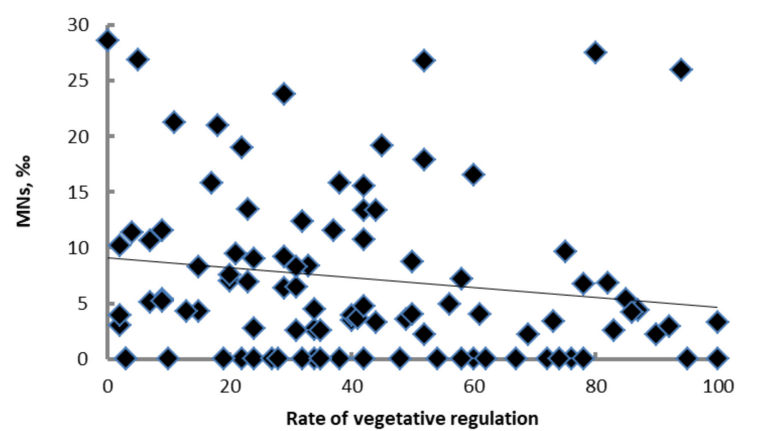

b)

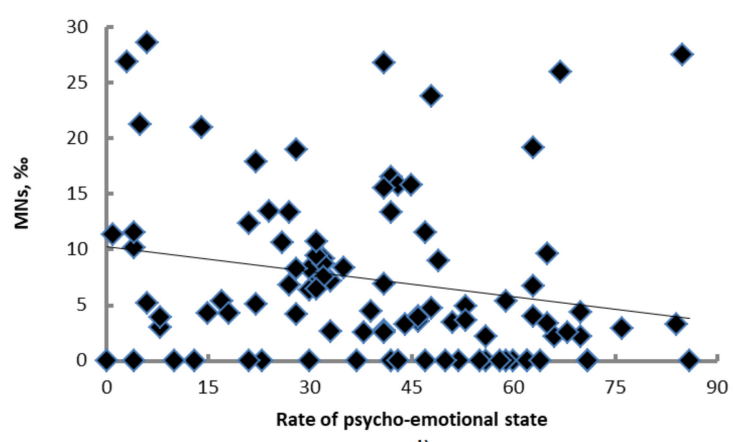

d)

Figure 2. Relationships between the frequency of cells with micronuclei (MN) and the physiological state of the organism in miners older than 30 years: (a) level of body adaptation; (b) rate of vegetative regulation; (c) stress index; (d) psycho-emotional state.

\section{Discussion}

The main objective of the study was to evaluate the genotoxic and cytotoxic effects of natural sources of ionizing radiation in mines upon the miners' buccal epithelium and their psychophysiological state. We assumed that the main method of exposure of miners could be the inhalation of radon in mines. Therefore, to identify possible genotoxic effects, a micronucleus test was chosen on the cells of the tissue in direct contact with airborne contaminants. In addition, the buccal epithelium is characterized by a high rate of renewal, and therefore a more pronounced sensitivity to mutagens of endogenous and exogenous nature. The BMCyt assay allows you to identify a wide range of events - these are not only effects associated with genome damage (the formation of micronuclei and nuclear protrusions), but also effects with various manifestations of cell death variants-apoptosis and necrosis (condensed chromatin in the nucleus, pycnosis of the nucleus, karyorrhexis, etc.) $[33,38,39]$. Most of the studies were focused on assessing only the frequency of occurrence of cells with MN, although a number of studies also take into account the various stages of nuclear destruction. In this present study, the BMCyt assay with HRV data was used to investigate biomarkers for maladaptation due to genotoxic exposure. We tried to choose settlements with a similar level of industrial pollution. The study itself was carried out in the winter period, when in both settlements the main source of pollution was preserved by snow cover.

The frequency of cells with chromatin condensation in the nucleus is the most sensitive indicator of the BMCyt assay, which provides earlier detection of exposure to toxic effects [40]. Various authors have noted an increase in the frequency of cells with chromatin condensation in consumers of 
tobacco gum [28], in road workers [41], in those exposed to paints [42], artificial sources of ionizing radiation [43], and also when aging [33]. We found three-fold excess in the frequency of occurrence of cells with chromatin condensation in the exposed group relative to the unexposed (Table 2).

MNs are recognized biomarkers of the genotoxic effects of various factors. They represent a separate part of the genetic material outside the main nucleus, which is either a fragment of a chromosome formed as a result of DNA damage, or one or more whole chromosomes lagging behind in anaphase and not included in the main nucleus [44]. An increase in the frequency of cells with micronuclei in the oral cavity is the earliest manifestation of the risk of oral cancer [13]. This study shows a significant almost threefold increase in the frequency of occurrence of cells with micronuclei in a group of miners of both age groups relative to the unexposed group (Table 2).

The frequency of protrusion such as nuclear buds and broken eggs is also an important indicator of micronucleus tissue. The mechanism of their appearance until the end is not fully understood and is a controversial issue. It has been suggested that protrusions are the result of degenerative cellular changes [45]. However, a number of authors explain such nuclear anomalies as a result of genotoxic effects [46-48], epigenetic processes [49], or as a result of the budding of the nucleus during the S-phase [50]. At the same time, a number of researchers propose to consider their formation as a result of cytogenetic disorders since a significant increase in the frequency of nuclear protrusions was shown during exposure to mutagens [51-54]. At the same time, the authors suggest that the onset of nuclear buds may be associated with the elimination of amplified DNA and DNA repair processes $[45,49,50,55]$. In our study, the analysis of protrusions revealed a significant excess of four times the frequency of occurrence of broken eggs in the unexposed group (Table 2). We assume that in the exposed group, potential broken eggs are transferred into MN due to clastogenic effects. However, since in this study we did not determine centromeres in MNs, we cannot confidently assert the presence of clastogenic effects. It is known that clastogen-induced MNs differ from spontaneously MNs in that they contain acentric fragments rather than whole chromosomes with centromeres [56-63]. Unfortunately, standardized assessment methods are not described for buccal epithelium cells [33]. We also do not exclude the possibility that the formation of the non-exposed control group could have included effects that were due to other factors.

It is believed that the process of clastogenesis can proceed to the stage of mutagenesis, which in turn can pass to the stage of carcinogenesis. However, the human body has a homeostasis, which is implemented within the cells of the buccal epithelium by means of karyorrhexis and karyolysis due to the elimination of damaged cells. The dynamics of carcinogenesis in the buccal epithelium is reflected in the repair index (RI) [37,64]. In our study, RI was significantly lower in the miners than in the unexposed group. This indicates a violation of the processes of elimination of damaged buccal epithelial cells and a higher risk of carcinogenesis in miners. It should be noted that in this study we limited ourselves to calculating the RI for buccal cells. However, comet assay on various tissues is also used to assess DNA repair $[65,66]$. Thus, Brazilian researchers successfully combine the BMCyt assay and comet assay in human lymphocytes to assess genotoxicity and reparation when exposed to xenobiotics [67-69].

To assess the degree of disruption of the proliferation of buccal epithelial cells, cells with two and more nucleus and double nucleus were taken into account. There is evidence that binuclear and multinucleated cells are formed mainly as a result of polyploidizing acitokinetic mitosis [70] and their frequency may increase in response to irradiation [71]. A double nucleus is formed in the process of incomplete mitosis as a result of damage to the spindle of division, and not only cytotomy, but also karyotomy is disturbed [72]. The origin of the binuclear cell is not related to the direct exposure of the genotoxicant to DNA. It is assumed that this effect occurs at the final stages of cell division [72]. We did not reveal significant differences in these indicators between the exposed and unexposed groups (Table 2). Consequently, production factors at this mine do not affect the processes of cytotomy and karyotomy in the buccal epithelium. 
Throughout life, the human body is exposed to various external and internal factors with the development of short-term and long-term processes of corresponding adaptation. This is especially true for individual professional groups associated with the impact of stress factors, in specifically within the employees of mining enterprises [73-75]. Heart rate variability analysis of HRV is an adequate method to assess the level of stress in their daily activities. HRV is the result of the rhythmic activity of the autonomous cells of the sinus node, the modulating effects of the autonomic and central nervous systems, humoral and reflex effects [76,77]. In cases where the current activity of the sympathetic and parasympathetic divisions is the result of the multi-loop and multi-level blood circulation regulation, then over time the parameters will achieve an optimal adaptive response that reflects the adaptation of the whole organism [78]. Therefore, the analysis of the structure of HRV provides important information on the state of the vegetative regulation of the cardiovascular system and the organism as a whole. A comprehensive assessment of heart rate variability provides an assessment of functional states, rather than specific nosological forms. One of the indicators for evaluating such reactions is the adaptative potential and the assessment of the psycho-emotional state. They are calculated in data points by a special algorithm [35].

In this paper, we compared the BMCyt assay data with body mass index and HRV values of miners in order to identify additional biomarkers. An interesting reliable pattern has been revealed in miners under the age of 30 years that the frequency of nucleus protrusions correlates significantly with the body mass index. According to Mullner et al. $[79,80]$ the frequency of buccal epithelium cells with $\mathrm{MN}$ increases with obesity and type 2 diabetes. A similar pattern has been shown on lymphocyte cells to increase the frequency of cells with micronuclei in obesity, diabetes and cardiovascular disease [80]. Recent studies have shown that factors involved in DNA repair also regulate cellular metabolism in response to DNA damage to avoid further genomic instability [81-83]. In mice, it was shown that obesity is associated with an increase in DNA damage. It is assumed that there is a relationship between aberant leptin signaling and age-associated DNA-damage $[17,84]$.

In miners older than 30 years, the frequency of cells with $\mathrm{MN}$ is associated with the stress index of regulatory mechanisms. The higher the stress index, the more pronounced the tone of the sympathetic nervous system, the more rigid the rhythm and the more cardiointervals of the same type. An increase in the stress index leads to a decrease in the adaptation potential, vegetative regulation, and the psycho-emotional state. At the same time, as the stress index decreases and the psycho-emotional state increases, the frequency of cells with chromatin condensation increases. It can be assumed that the frequency of cells with chromatin condensation may be influenced by the psycho-emotional state of a person.

It should be noted that most of the works devoted to the study of genotoxic effects using the BMCyt assay in miners are related to coal mining $[54,68,69,85,86]$. In these works, the authors showed a significant increase in the frequency of $\mathrm{MN}$ in buccal epithelium cells in coal miners. Unfortunately, we have not found any works devoted to the study of genotoxic effects using BMCyt assay in mines with an emphasis on natural radioactivity. In studies, such effects are mainly evaluated on peripheral blood lymphocytes for uranium miners from Hungary, Czech Republic and Germany using micronucleus-centromere assay and chromosome aberration analyzes $[60,87,88]$. Marsh and co-authors [89] created dosimetric calculations for a typical German miner exposed to radon gas, radon progeny and long-lived radionuclides (LLR) present in the uranium ore dust and to external gamma radiation. They showed that the absorbed dose to the central regions of the lung is dominated by the dose arising from exposure to radon progeny, whereas the absorbed dose to the red bone marrow is dominated by the external gamma dose. The results obtained by us testify to the induction of possible clastogenic effects and a decrease in the level of reparation in the buccal epithelium cells due to the exposure various production factors in the extraction of loparite ore. 
Author Contributions: D.P. and A.M. designed the project, performed the experiments; D.P., A.M. and V.M. performed the analysis of the results and the interpretation of the data; D.P. wrote the initial draft of the paper which was further modified by A.M. and V.M. after further discussions with all the authors; V.M. revised the paper and refined the language.

Funding: This research received no external funding.

Acknowledgments: The authors express their deepest gratitude to N.K. Belisheva for research assistance. We also appreciate unknown reviewers for constructive comments and corrections.

Conflicts of Interest: The authors declare no conflict of interest.

\section{References}

1. Protection against Radon-222 at Home and at Work; A Report of a Task Group of the International Commission on Radiological Protection; Pergamon: Oxford, UK, 1993; pp. 1-45.

2. Tomasek, L.; Rogel, A.; Tirmarche, M.; Mitton, N.; Laurier, D. Lung cancer in French and Czech uranium miners: Radon-associated risk at low exposure rates and modifying effects of time since exposure and age at exposure. Radiat. Res. 2008, 169, 125-137. [CrossRef] [PubMed]

3. Khan, M.A.; Cross, F.T.; Buschbom, R.L.; Brooks, A.L. inhaled radon-induced genotoxicity in wistar rat, syrian-hamster, and chinese-hamster deep-lung fibroblasts in-vivo. Mutat. Res.-Environ. Mutagen. Relat. Subj. 1995, 334, 131-137. [CrossRef]

4. Goodhead, D.T. Understanding and characterisation of the risks to human health from exposure to low levels of radiation. Radiat. Prot. Dosim. 2009, 137, 109-117. [CrossRef] [PubMed]

5. Pelevina, I.I.; Afanasjev, G.G.; Aleshchenko, A.V.; Antoshchina, M.M.; Gotlib, V.Y.; Konradov, A.A.; Kudryashova, O.V.; Lizunova, E.Y.; Osipov, A.N.; Ryabchenko, N.I.; et al. Molecular and Cellular Consequences of the Chernobyl Accident. Radiat. Biol. Radioecol. 2011, 51, 154-164. [CrossRef]

6. Natarajan, A.T. Reflections on a lifetime in cytogenetics. Mutat. Res.-Rev. Mut. Res. 2012, 751, 1-6. [CrossRef] [PubMed]

7. Sakamoto-Hojo, E.T. Lessons from the accident with (137)Cesium in Goiania, Brazil: Contributions to biological dosimetry in case of human exposure to ionizing radiation. Mutat. Res.-Genet. Toxicol. Environ. Mutagen. 2018, 836, 72-77. [CrossRef] [PubMed]

8. Jha, A.N.; Sharma, T. Enhanced frequency of chromosome-aberrations in workers occupationally exposed to diagnostic x-rays. Mut. Res. 1991, 260, 343-348. [CrossRef]

9. Balasem, A.N.; Ali, A.S.K.; Mosa, H.S.; Hussain, K.O. Chromosomal aberration analysis in peripheral lymphocytes of radiation workers. Mutat. Res. 1992, 271, 209-211. [CrossRef]

10. Barquinero, J.F.; Barrios, L.; Caballin, M.R.; Miro, R.; Ribas, M.; Subias, A.; Egozcue, J. Cytogenetic analysis of lymphocytes from hospital workers occupationally exposed to low-levels of ionizing-radiation. Mutat. Res. 1993, 286, 275-279. [CrossRef]

11. Brenner, D.J.; Miller, R.C.; Huang, Y.; Hall, E.J. The biological effectiveness of radon-progeny alpha-particles.3. quality factors. Radiat. Res. 1995, 142, 61-69. [CrossRef] [PubMed]

12. Hagelstrom, A.H.; Gorla, N.B.; Larripa, I.B. Chromosomal damage in workers occupationally exposed to chronic low-level ionizing-radiation. Toxicol. Lett. 1995, 76, 113-117. [CrossRef]

13. Cardoso, R.S.; Takahashi-Hyodo, S.; Peitl, P.; Ghilardi-Neto, T.; Sakamoto-Hojo, E.T. Evaluation of chromosomal aberrations, micronuclei, and sister chromatid exchanges in hospital workers chronically exposed to ionizing radiation. Teratog. Carcinog. Mutagen. 2001, 21, 431-439. [CrossRef] [PubMed]

14. Mihalache, D.; Preoteasa, V.; Petrescu, A.I. Incidence of radiation-induced micronuclei in occupationally exposed subjects. Romanian J. Biophys. 2007, 17, 119-128.

15. Abo-Elmagd, M.; Daif, M.M.; Eissa, H.M. Cytogenetic effects of radon inhalation. Radiat. Meas. 2008, 43, 1265-1269. [CrossRef]

16. Zolzer, F.; Skalicka, Z.F.; Havrankova, R.; Hon, Z.; Navratil, L.; Rosina, J.; Skopek, J. Enhanced frequency of micronuclei in lymphocytes from current as opposed to former uranium miners. J. Appl. Biomed. 2011, 9 , 151-156. [CrossRef]

17. Shukla, P.C.; Singh, K.K.; Yanagawa, B.; Teoh, H.; Verma, S. DNA damage repair and cardiovascular diseases. Can. J. Cardiol. 2010, 26, 13-16. [CrossRef] 
18. De Flora, S.; Izzotti, A. Mutagenesis and cardiovascular diseases Molecular mechanisms, risk factors, and protective factors. Mutat. Res.-Fundam. Mol. Mech. Mutagen. 2007, 621, 5-17. [CrossRef] [PubMed]

19. Aragno, M.; Mastrocola, R.; Alloatti, G.; Vercellinatto, I.; Bardini, P.; Geuna, S.; Catalano, M.; Danni, O.; Boccuzzi, G. Oxidative stress triggers cardiac fibrosis in the heart of diabetic rats. Endocrinology 2008, 380-388. [CrossRef] [PubMed]

20. Ansley, D.M.; Wang, B.H. Oxidative stress and myocardial injury in the diabetic heart. J. Pathol. 2013, 229, 232-241. [CrossRef] [PubMed]

21. Ingel, F.I. Perspectives of micronuclear test in human lymphocytes cultivated in cytogenetic block conditions. Part 1: Cell proliferation. Ecol. Genet. 2006, 3, 7-20. [CrossRef]

22. Pelevina, I.I.; Oradovskaya, I.V.; Mansurova, Y.G.; Aleschenko, A.V.; Antoschina, M.M.; Kudriashova, O.V.; Lizunova, E.Y.; Nikonova, M.F.; Osipov, A.N.; Ryabchenko, N.I.; et al. The Connection Between Molecular Cellular Parameters and Immune Status of Liquidators after Chernobyl Accident. Radiat. Biol. Radioecol. 2010, 50, 501-509.

23. Holland, N.; Bolognesi, C.; Kirsch-Volders, M.; Bonassi, S.; Zeiger, E.; Knasmueller, S.; Fenech, M. The micronucleus assay in human buccal cells as a tool for biomonitoring DNA damage: The HUMN project perspective on current status and knowledge gaps. Mutat. Res.-Rev. Mutat. Res. 2008, 659, 93-108. [CrossRef] [PubMed]

24. Bonassi, S.; Ugolini, D.; Kirsch-Volders, M.; Stromberg, U.; Vermeulen, R.; Tucker, J.D. Human population studies with cytogenetic biomarkers: Review of the literature and future prospectives. Environ. Mol. Mutagen. 2005, 45, 258-270. [CrossRef] [PubMed]

25. Bonassi, S.; Coskun, E.; Ceppi, M.; Lando, C.; Bolognesi, C.; Burgaz, S.; Holland, N.; Kirsh-Volders, M.; Knasmueller, S.; Zeiger, E.; et al. The HUMAN Micronucleus project on exfoliated buccal cells (HUMNXL): The role of life-style, host factors, occupational exposures, health status, and assay protocol. Mutat. Res.-Rev. Mutat. Res. 2011, 728, 88-97. [CrossRef] [PubMed]

26. Melnik, N.A.; Ikkonen, P.V. Studying of the main sources of radiation at the enterprise for production the rare metals ores. Surv. Samara Sci. Cent. Russ. Acad. Sci. 2012, 5, 802-805.

27. Report on the State and Protection of the Environment of the Murmansk Region in 2013; Ministry of Natural Resources and Ecology of Murmansk: Murmansk, Russia, 2014.

28. Tolbert, P.E.; Shy, C.M.; Allen, J.W. Micronuclei and other nuclear anomalies in buccal smears-Methods development. Mutat. Res. 1992, 271, 69-77. [CrossRef]

29. Ware, J.E. SF-36 health survey update. Spine 2000, 25, 3130-3139. [CrossRef] [PubMed]

30. Doskin, V.A.; Lavrent'eva, N.A.; Strongina, O.M.; Shară, V.B. “SAN” psychological test applicable to studies in the field of work physiology. Gigiena Truda Professional'nye Zabolevaniia 1975, 5, 28-35.

31. Spielberg, T.E. Treating depression and anxiety in primary care. N. Engl. J. Med. 1992, 327, 731. [PubMed]

32. Korkushko, O.V. Clinical Cardiology in Geriatrics; Medicine: Moscow, Russia, 1980; Volume 288, p. 288.

33. Thomas, P.; Holland, N.; Bolognesi, C.; Kirsch-Volders, M.; Bonassi, S.; Zeiger, E.; Knasmueller, S.; Fenech, M. Buccal micronucleus cytome assay. Nat. Protoc. 2009, 4, 825-837. [CrossRef] [PubMed]

34. Camm, A.J.; Malik, M.; Bigger, J.T.; Breithardt, G.; Cerutti, S.; Cohen, R.J.; Coumel, P.; Fallen, E.L.; Kennedy, H.L.; Kleiger, R.E.; et al. Heart rate variability-Standards of measurement, physiological interpretation, and clinical use. Circulation 1996, 93, 1043-1065.

35. The System of Complex Computer Studies of the Functional State of the Human Body "Omega-M"; Dinamika: St. Petersburg, Russia, 2010; p. 71.

36. Petrashova, D.A.; Burtsev, A.V. Development of a database for the micronucleus test upon human cells. Her. Kola Sci. Cent. RAS 2016, 2, 124-136.

37. Ramirez, A.; Saldanha, P.H. Micronucleus investigation of alcoholic patients with oral carcinomas. Genet. Mol. Res. (GMR) 2002, 1, 246-260. [PubMed]

38. Poly-Organized Micro-Nucliear Test in Ecological and Hygienic Researches; Genius Media: Frauenfeld, Switzerland, 2007; p. 312.

39. Torres-Bugarin, O.; Zavala-Cerna, M.G.; Nava, A.; Flores-Garcia, A.; Ramos-Ibarra, M.L. Potential Uses, Limitations, and Basic Procedures of Micronuclei and Nuclear Abnormalities in Buccal Cells. Dis. Mark. 2014. [CrossRef] [PubMed] 
40. Krivtsova, E.K.; Yurchenko, V.V.; Ingel, F.; Urtseva, N.A.; Makarova, A.S. Buccal micronucleus cytome assay in the system of the hygienic evaluation of learning conditions of students of different faculties of the same university. Gigiena Sanitaria (Hyg. Sanitat. Russ. J.) 2018, 97, 179-188. [CrossRef]

41. Torres-Bugarin, O.; Anda-Casillas, A.D.; Ramirez-Munoz, M.P.; Sanchez-Corona, J.; Cantu, J.M.; Zuniga, G. Determination of diesel genotoxicity in firebreathers by micronuclei and nuclear abnormalities in buccal mucosa. Mutat. Res.-Genet. Toxicol. Environ. Mutagen. 1998, 413, 277-281. [CrossRef]

42. Cassini, C.; Calloni, C.; Bortoloni, G.; Garcta, S.C.; Dornelles, M.A.; Henriques, J.A. Occupational risk assessment of oxidative stress and genotoxicity in workers exposed to paints during a working week. Int. J. Occup. Med. Environ. Health. 2011, 24, 308-322. [CrossRef] [PubMed]

43. Angelieri, F.; Moleirinho, T.D.G.; Carlin, V.; Oshima, C.T.F.; Ribeiro, D.A. Biomonitoring of oral epithelial cells in smokers and non-smokers submitted to panoramic X-ray: Comparison between buccal mucosa and lateral border of the tongue. Clin. Oral Investig. 2010, 14, 669-674. [CrossRef] [PubMed]

44. Sycheva, L.P. Biological value, scoring criteria and limits of a variation of a full spectrum karyological indexes of exfoliated cells for estimation of human cytogenetic status. Med. Genet. 2007, 6, 3-12.

45. Nersesyan, A.K. Nuclear buds in exfoliated human cells. Mutat. Res.-Genet. Toxicol. Environ. Mutagen. 2005, 588, 64-68. [CrossRef] [PubMed]

46. Serrano-Garcia, L.; Montero-Montoya, R. Micronuclei and chromatid buds are the result of related genotoxic events. Environ. Mol. Mutagen. 2001, 38, 38-45. [CrossRef] [PubMed]

47. Montero, R.; Serrano, L.; Davila, V.; Segura, Y.; Arrieta, A.; Fuentes, R.; Abad, I.; Valencia, L.; Sierra, P.; Camacho, R. Metabolic polymorphisms and the micronucleus frequency in buccal epithelium of adolescents living in an urban environment. Environ. Mol. Mutagen. 2003, 42, 216-222. [CrossRef] [PubMed]

48. Zeljezic, D.; Garaj-Vrhovac, V. Chromosomal aberrations, micronuclei and nuclear buds induced in human lymphocytes by 2,4-dichlorophenoxyacetic acid pesticide formulation. Toxicology 2004, 200, 39-47. [CrossRef] [PubMed]

49. Fenech, M.; Crott, J.W. Micronuclei, nucleoplasmic bridges and nuclear buds induced in folic acid deficient human lymphocytes-Evidence for breakage-fusion-bridge cycles in the cytokinesis-block micronucleus assay. Mutat. Res.-Fundam. Mol. Mech. Mutagen. 2002, 504, 131-136. [CrossRef]

50. Shimizu, N.; Itoh, N.; Utiyama, H.; Wahl, G.M. Selective entrapment of extrachromosomally amplified DNA by nuclear budding and micronucleation during S phase. J. Cell Biol. 1998, 140, 1307-1320. [CrossRef] [PubMed]

51. Gadhia, P.K.; Thumbar, R.P.; Kevadiya, B. Cytome Assay of Buccal Epithelium for Bio-monitoring Genotoxic Assessment of Benzene Exposure among Petrol Pump Attendants. Int. J. Hum. Genet. 2010, 10, $239-245$. [CrossRef]

52. Celik, A.; Yildirim, S.; Ekinci, S.Y.; Tasdelen, B. Bio-monitoring for the genotoxic assessment in road construction workers as determined by the buccal micronucleus cytome assay. Ecotoxicol. Environ. Saf. 2013, 92, 265-270. [CrossRef] [PubMed]

53. Benedetti, D.; Nunes, E.; Sarmento, M.; Porto, C.; dos Santos, C.E.I.; Dias, J.F.; da Silva, J. Genetic damage in soybean workers exposed to pesticides: Evaluation with the comet and buccal micronucleus cytome assays. Mutat. Res.-Genet. Toxicol. Environ. Mutagen. 2013, 752, 28-33. [CrossRef] [PubMed]

54. Meyer, A.V.; Tolochko, T.A.; Litvin, A.V.; Minina, V.I.; Kulemin, Y.E. Karyological status of buccal epithelial cells of miners with occupational lung pathologies. Gigiena Sanitaria (Hyg. Sanitat. Russ. J.) 2018, 97, 220-225. [CrossRef]

55. Shimizu, N.; Kamezaki, F.; Shigematsu, S. Tracking of microinjected DNA in live cells reveals the intracellular behavior and elimination of extrachromosomal genetic material. Nucleic Acids Res. 2005, 33, 6296-6307. [CrossRef] [PubMed]

56. Norppa, H.; Renzi, L.; Lindholm, C. Detection of whole chromosomes in micronuclei of cytokinesis-blocked human-lymphocytes by antikinetochore staining and in-situ hybridization. Mutagenesis 1993, 8, 519-525. [CrossRef] [PubMed]

57. Vral, A.; Thierens, H.; De Ridder, L. In vitro micronucleus-centromere assay to detect radiation-damage induced by low doses in human lymphocytes. Int. J. Radiat. Biol. 1997, 71, 61-68. [PubMed] 
58. Ramirez, M.J.; Surralles, J.; Galofre, P.; Creus, A.; Marcos, R. FISH analysis of1cen-1q12 breakage, chromosome 1 numerical abnormalities and centromericcontent of micronuclei in buccal cells from thyroid cancer and hyperthyroidismpatients treated with radioactive iodine. Mutagenesis 1999, 14, 121-127. [CrossRef] [PubMed]

59. Wojcik, A.; Kowalska, M.; Bouzyk, E.; Buraczewska, I.; Kobialko, G.; Jarocewicz, N.; Szumiel, I. Validation of the micronucleus-centromere assay for biological dosimetry. Genet. Mol. Biol. 2000, 23, 1083-1085. [CrossRef]

60. Kryscio, A.; Muller, W.U.U.; Wojcik, A.; Kotschy, N.; Grobelny, S.; Streffer, C. A cytogenetic analysis of the long-term effect of uranium mining on peripheral lymphocytes using the micronucleus-centromere assay. Int. J. Radiat. Biol. 2001, 77, 1087-1093. [CrossRef] [PubMed]

61. Van Schooten, F.J.; Nia, A.B.; De Flora, S.; D'Agostini, F.; Izzotti, A.; Camoirano, A.; Balm, A.J.M.; Dallinga, J.W.; Bast, A.; Haenen, G.; et al. Effects of oral administration of N-acetyl-L-cysteine: A multi-biomarker study in smokers. Cancer Epidemiol. Biomark. Prev. 2002, 11, 167-175.

62. Schwartz, J.L.; Muscat, J.E.; Baker, V.; Larios, E.; Stephenson, G.D.; Guo, W.; Xie, T.P.; Gu, X.B.; Chung, F.L. Oral cytology assessment by flow cytometry of DNA adducts, aneuploidy, proliferation and apoptosis shows differences between smokers and non-smokers. Oral Oncol. 2003, 39, 842-854. [CrossRef]

63. Thierens, H.; Vral, A. The micronucleus assay in radiation accidents. Annali Dell Istituto Superiore Sanita 2009, 45, 260-264.

64. Diler, S.B.; Celik, A. Cytogenetic Biomonitoring of Carpet Fabric Workers Using Micronucleus Frequency, Nuclear Changes, and the Calculation of Risk Assessment by Repair Index in Exfoliated Mucosa Cells. DNA Cell Biol. 2011, 30, 821-827. [CrossRef] [PubMed]

65. Collins, A.R. The comet assay for DNA damage and repair - Principles, applications, and limitations. Mol. Biotechnol. 2004, 26, 249-261. [CrossRef]

66. Azqueta, A.; Slyskova, J.; Langie, S.A.S.; Gaivao, I.O.; Collins, A. Comet assay to measure DNA repair: Approach and applications. Front. Genet. 2014, 5, 8. [CrossRef] [PubMed]

67. Coronas, M.V.; Pereira, T.S.; Rocha, J.A.V.; Lemos, A.T.; Fachel, J.M.G.; Salvadori, D.M.F.; Vargas, V.M.F. Genetic biomonitoring of an urban population exposed to mutagenic airborne pollutants. Environ. Int. 2009, 35, 1023-1029. [CrossRef] [PubMed]

68. Pinto, E.A.D.; Garcia, E.M.; de Almeida, K.A.; Fernandes, C.F.L.; Tavella, R.A.; Soares, M.C.F.; Baisch, P.R.M.; Muccillo-Baisch, A.L.; da Silva, F.M.R. Genotoxicity in adult residents in mineral coal region-a cross-sectional study. Environ. Sci. Pollut. Res. 2017, 24, 16806-16814. [CrossRef] [PubMed]

69. da Silva, F.M.R.; Tavella, R.A.; Fernandes, C.L.F.; Soares, M.C.F.; de Almeida, K.A.; Garcia, E.M.; Pinto, E.A.D.; Baisch, A.L.M. Genotoxicity in Brazilian coal miners and its associated factors. Hum. Exp. Toxicol. 2018, 37, 891-900. [CrossRef] [PubMed]

70. Brodskii, V.I.; Uryvaeva, I.V. Cell Polyploidy, Proliferation and Differentiation; Science: Moscow, Russia, 1981; p. 237.

71. Koss, L.G. Diagnostic Cytology and Its Histopathologic Bases; J.B. Lippincott Co.: Philadelphia, PA, USA; Toronto, ON, Canada, 1979; Volume 2, p. 1266.

72. Iurchenko, V.V. Cytogenetic disorders in the human cheek epithelium during exposure to genotoxicants. Toxicol. Bull. 2005, 6, 14-21.

73. Gondareva, L.N.; Kulkybaev, G.A.; Mindubaeva, F.A. Prognostic assessment of the development of professional adaptation in miners of coal mines. Occup. Health Ind. Ecol. 2000, 1, 10-13.

74. Thakur, V.; Richards, R.; Reisin, E. Obesity, hypertension, and the heart. Am. J. Med. Sci. 2001, 321, $242-248$. [CrossRef] [PubMed]

75. Martynova, A.; Pryanichnikov, S.V.; Mikhailov, R.E.; Belisheva, N. Features of Heart rate variability of mining production workers in the Murmansk region. Hum. Ecol. 2017, 3, 31-38.

76. Pomeranz, B.; Macaulay, R.J.B.; Caudill, M.A.; Kutz, I.; Adam, D.; Gordon, D.; Kilborn, K.M.; Barger, A.C.; Shannon, D.C.; Cohen, R.J.; et al. Assessment of autonomic function in humans by heart-rate spectral-analysis. Am. J. Physiol. 1985, 248, H151-H153. [CrossRef] [PubMed]

77. Malliani, A.; Pagani, M.; Lombardi, F.; Cerutti, S. Cardiovascular neural regulation explored in the frequency-domain. Circulation 1991, 84, 482-492. [CrossRef] [PubMed]

78. Anokhin, P.K. Principles of System Organization of Functions; Nauka: Moscow, Russia, 1973; p. 316. 
79. Mullner, E.; Brath, H.; Nersesyan, A.; Nitz, M.; Petschnig, A.; Wallner, M.; Knasmuller, S.; Wagner, K.H. Nuclear anomalies in exfoliated buccal cells in healthy and diabetic individuals and the impact of a dietary intervention. Mutagenesis 2014, 29, 1-6. [CrossRef] [PubMed]

80. Andreassi, M.G.; Barale, R.; Iozzo, P.; Picano, E. The association of micronucleus frequency with obesity, diabetes and cardiovascular disease. Mutagenesis 2011, 26, 77-83. [CrossRef] [PubMed]

81. Berkers, C.R.; Maddocks, O.D.K.; Cheung, E.C.; Mor, I.; Vousden, K.H. Metabolic Regulation by p53 Family Members. Cell Metab. 2013, 18, 617-633. [CrossRef] [PubMed]

82. Jeong, S.M.; Xiao, C.Y.; Finley, L.W.S.; Lahusen, T.; Souza, A.L.; Pierce, K.; Li, Y.H.; Wang, X.X.; Laurent, G.; German, N.J.; et al. SIRT4 Has Tumor-Suppressive Activity and Regulates the Cellular Metabolic Response to DNA Damage by Inhibiting Mitochondrial Glutamine Metabolism. Cancer Cell 2013, 23, 450-463. [CrossRef] [PubMed]

83. Imai, S.; Guarente, L. NAD(+) and sirtuins in aging and disease. Trends Cell Biol. 2014, 24, 464-471. [CrossRef] [PubMed]

84. Barouch, L.A.; Gao, D.Q.; Chen, L.; Miller, K.L.; Xu, W.H.; Phan, A.C.; Kittleson, M.M.; Minhas, K.M.; Berkowitz, D.E.; Wei, C.M.; et al. Cardiac myocyte apoptosis is associated with increased DNA damage and decreased survival in murine models of obesity. Circ. Res. 2006, 98, 119-124. [CrossRef] [PubMed]

85. Rohr, P.; da Silva, J.; da Silva, F.R.; Sarmento, M.; Porto, C.; Debastiani, R.; dos Santos, C.E.I.; Dias, J.F.; Kvitko, K. Evaluation of genetic damage in open-cast coal mine workers using the buccal micronucleus cytome assay. Environ. Mol. Mutagen. 2013, 54, 65-71. [CrossRef] [PubMed]

86. Leon-Mejia, G.; Quintana, M.; Debastiani, R.; Dias, J.; Espitia-Perez, L.; Hartmann, A.; Henriques, J.A.P.; Da Silva, J. Genetic damage in coal miners evaluated by buccal micronucleus cytome assay. Ecotoxicol. Environ. Saf. 2014, 107, 133-139. [CrossRef] [PubMed]

87. Meszaros, G.; Bognar, G.; Koteles, G.J. Long-term persistence of chromosome aberrations in uranium miners. J. Occup. Health 2004, 46, 310-315. [CrossRef] [PubMed]

88. Zolzer, F.; Hon, Z.; Skalicka, Z.F.; Havrankova, R.; Navratil, L.; Rosina, J.; Skopek, J. Persistence of Genetic Damage in Lymphocytes from Former Uranium Miners. Cytogenet. Genome Res. 2012, 136, $288-294$. [CrossRef] [PubMed]

89. Marsh, J.W.; Blanchardon, E.; Gregoratto, D.; Hofmann, W.; Karcher, K.; Nosske, D.; Tomasek, L. Dosimetric calculations for uranium miners for epidemiological studies. Radiat. Prot. Dosim. 2012, 149, 371-383. [CrossRef] [PubMed] 